\title{
Carotenoid Concentration and Composition in Winter Squash: Variability Associated with Different Cultigens, Harvest Maturities, and Storage Times
}

\author{
Jennifer Bonina-Noseworthy ${ }^{1}$ and J. Brent Loy ${ }^{2}$ \\ Department of Biological Sciences, University of New Hampshire, Durham, \\ NH 03824 \\ Joanne Curran-Celentano \\ Department of Molecular, Cellular, and Biomedical Sciences, University of \\ New Hampshire, Durham, NH 03824
}

Rebecca Sideman

Department of Biological Sciences, University of New Hampshire, Durham, NH 03824

\section{Dean A. Kopsell \\ Plant Sciences Department, University of Tennessee, Knoxville, TN 37996}

Additional index words. Cucurbita species, human health, $\alpha$-carotene, $\beta$-carotene, lutein, zeaxanthin

\begin{abstract}
In the present study, carotenoid concentrations and profiles of carotenoids were determined at harvest and during storage in fruit of several cultigens of winter squash, including several New Hampshire (NH) breeding lines, the cultivars Waltham Butternut and Puritan Butternut in Cucurbita moschata (Duch.), and the hybrid cultivars Sunshine, Eclipse, Space Station, and Thunder in Cucurbita maxima (Duch.). Cultigens were grown at research farms in either Madbury or Durham, NH, in 2007, 2008, and 2009, and fruit were harvested at either 40 or 60 days after pollination (DAP), and stored for 0,30 , or 60 days at $14{ }^{\circ} \mathrm{C}$ before sampling. Total carotenoid concentrations were determined spectrophotometrically and carotenoid profiles were determined using high-performance liquid chromatography (HPLC). Carotenoid concentrations in fruit samples of $C$. maxima cultigens harvested at 60 DAP ranged from 146 to $320 \mu \mathrm{g} \cdot \mathrm{g}^{-1}$ fresh weight $(\mathrm{FW})$, compared with concentrations of 274 to $623 \mu \mathrm{g} \cdot \mathrm{g}^{-1} \mathrm{FW}$ after storage for 60 days. Carotenoid concentrations were lower among $C$. moschata cultigens, ranging from 42 to $145 \mu \mathrm{g} \cdot \mathrm{g}^{-1} \mathrm{FW}$ at $60 \mathrm{DAP}$, and from 84 to $239 \mu \mathrm{g} \cdot \mathrm{g}^{-1} \mathrm{FW}$ after 60 -day storage. The nutritionally important carotenoids, lutein, zeaxanthin, and $\beta$-carotene, comprised $41 \%$ to $63 \%$ of the total carotenoid profile in the $C$. maxima kabocha hybrids; whereas, the carotenoids neoxanthin and flavoxanthin comprised $37 \%$ to $59 \%$. $\beta$-Carotene and lutein were the major nutritionally beneficial carotenoids identified in 'Waltham Butternut' and three inbred lines of $C$. moschata, along with much smaller concentrations of $\alpha$-carotene. Neoxanthin and violaxanthin comprised between $14 \%$ and $29 \%$ of the total carotenoid profiles among the four cultigens analyzed. In the popular cultivar Waltham Butternut, the $\beta$-carotene concentration was $17.3 \mu \mathrm{g} \cdot \mathrm{g}^{-1} \mathrm{FW}$ at $60 \mathrm{DAP}$, but increased to a maximum of $57.8 \mu \mathrm{g} \cdot \mathrm{g}^{-1} \mathrm{FW}$ after storage for 30 days; whereas, lutein concentrations increased from $27.3 \mu \mathrm{g} \cdot \mathrm{g}^{-1} \mathrm{FW}$ at $60 \mathrm{DAP}$ to $44.6 \mu \mathrm{g} \cdot \mathrm{g}^{-1} \mathrm{FW}$ after 60 -day storage. In Sunshine, a popular kabocha cultivar, $\beta$-carotene increased from $26.0 \mu \mathrm{g} \cdot \mathrm{g}^{-1} \mathrm{FW}$ at $60 \mathrm{DAP}$ to $104 \mu \mathrm{g} \cdot \mathrm{g}^{-1} \mathrm{FW}$ after 60-day storage. Lutein + zeaxanthin concentrations in 'Sunshine' were $58.8 \mu \mathrm{g} \cdot \mathrm{g}^{-1} \mathrm{FW}$ at $60 \mathrm{DAP}$, but increased only to $71.8 \mu \mathrm{g} \cdot \mathrm{g}^{-1} \mathrm{FW}$ after 60 -day storage. Total carotenoid concentrations and carotenoid profiles in 'Sunshine' over three growing seasons, and in 'Waltham Butternut', 'NH.Mo421', and 'NH.Mo851' over two growing seasons, were similar.
\end{abstract}

Carotenoids are ubiquitous fat-soluble, yellow-, orange-, and red-pigmented compounds found in leaves as part of the chloroplast structure and in the chromoplasts of many root and fruit crops (Britton and Khachik, 2009). They are typically subdivided into two groups, hydrocarbons (carotenes) and the more polar xanthophylls or hydroxy-containing carotenoids, the latter often esterified to fatty acids. Carotenes, chiefly $\alpha$-carotene and $\beta$-carotene, and the xanthophyll, $\beta$-cryptoxanthin, are precursors to vitamin A, which has a significant role in vision, in maintaining a healthy immune system, and in regulation of gene expression during growth and development (Britton, 2009). Two xanthophylls, lutein and zeaxanthin, are present in the retina of humans and subhuman primates, and necessary for visual acuity and as a filter for short wave light (Schalch et al., 2009). They are also two of the six most prominent carotenoids in human blood plasma and tissues (Canene-Adams and Erdman, 2009). Other carotenoids found in plants, such as violaxanthin and neoxanthin, have an important function in photosynthesis and plant hormone physiology, but are largely absent in human plasma and organs, and have yet to be linked to a role in human health (Barua and Olson, 2001; Canene-Adams and Erdman, 2009; Khachik, 2009; Milborrow, 2001).

Mesocarp tissue of immature winter squash fruit is low in carotenoids, but carotenoid concentrations begin to progressively increase beginning $\approx 15$ to $20 \mathrm{~d}$ after fruit set (Boiteux et al., 2007; Kon and Shimba, 1988). Variation in total carotenoid concentrations in mature squash among cultivars in the three major species of winter squash, Cucurbita pepo, $C$. maxima, and $C$. moschata, have been reported (Azevedo-Meleiro and Rodriguez-Amaya, 2007; Boiteux et al., 2007; Jacobo-Valenzuela et al., 2011; Schaffer et al., 1986), as well as variation associated with harvest and storage times (Arima and Rodriguez-Amaya, 1988; Arvayo-Ortiz et al., 1994; Bycroft et al., 1999; Hopp et al., 1960). However, the diversity of germplasm analyzed is low, and in most reports, not representative of cultivars currently used in North America.

Since the late 1980 s, with the advancement of HPLC, the major carotenoids in the three major species of winter squash have been identified (Azevedo-Meleiro and Rodriguez-Amaya, 2007; González et al., 2001; Jacobo-Valenzuela et al., 2011; Khachik and Beecher, 1988), including nutritionally important carotenes, $\alpha$-carotene and $\beta$-carotene, and the xanthophyll lutein. In two of the most recent studies involving North American cultivars, the complete carotenoid profiles were not analyzed (Itle and Kabelka, 2009; Murkovic et al., 2002), and in the latter study, samples were not saponified. In squash, saponification is considered an important analytical procedure for HPLC analysis to allow for separation and quantification of xanthophylls, which are often esterified with fatty acids (Khachik, 2009; Khachik and Beecher, 1988; Rodriguez-Amaya, 2001). Carotenoids such as neoxanthin and violaxanthin may be abundant in winter squash (Azevedo-Meleiro and Rodriguez-Amaya, 2007), and for squash improvement through breeding, data on the proportion of these in the total carotenoid profile are important. There have been few studies on postharvest changes in carotenoid composition (Kon and Shimba, 1988; Zhang et al., 2014), but such changes could be important for assessing the nutritional status of winter squash. 
The objectives of this study were to determine the effects of year, differences in maturity at harvest, and storage time on total carotenoid concentrations and carotenoid profiles in fruit mesocarp tissue of several cultigens of $C$. maxima and C. moschata winter squash. In the present work, we included both a few popular commercial cultivars and also some NH breeding lines with diverse genetic parentage, most of which had been selected visually for intense orange pigmentation in fruit.

\section{Materials and Methods}

Plant material. In C. moschata, fruits from four $F_{5}$ (2007) and $F_{6}$ (2008 and 2009) breeding lines and three related, openpollinated cultivars of butternut squash were used in this study. The open-pollinated cultivars were Waltham Butternut (WBN), Puritan Butternut (PBN), and New Hampshire Baby Butternut (NHBBN). Seed of these cultivars were obtained from two generations of self-pollinations to improve uniformity. NHBBN was derived from the original Butternut cultivar crossed to Tsurukubi, a Korean cultivar, to eliminate the problem of crooknecking in butternut squash (Mutschler and Pearson, 1987; Yeager and Meader, 1957). Waltham Butternut, a widely grown cultivar, was derived from a cross between NHBBN and an African C. moschata accession, and PBN was a selection out of WBN, but with slightly smaller fruit (Mutschler and Pearson, 1987). Four University of New Hampshire (UNH) breeding lines, NH.Mo421, NH.Mo851, NH.Mo910, and NH.Mo2521, were derived from a cross of 'Bugle', a butternut release from Cornell University with intermediate powdery mildew resistance, to a breeding line [NH.(PxB)-118-24-21] with oblate fruit shape. The breeding line was derived from an heirloom strain from Maine with oblate fruit, crossed to a breeding line derived from an open-pollinated Peruvian accession with high carotenoid concentration.

In C. maxima, four kabocha UNH breeding lines bred for intense flesh color, NH.Max33-12, NH.Max6331, NH264, and NH.Max5273, were evaluated for total carotenoid concentrations. Carotenoid profiles were examined in four commercial kabocha hybrids, 'Eclipse', 'Thunder', 'Space Station' (Rupp Seeds, Waseon, $\mathrm{OH}$ ), and 'Sunshine' (Johnny's Selected Seeds, Albion, ME). Fruit of the NH kabocha hybrids are dark green at maturity and similar in appearance to the original Buttercup

Received for publication 30 Nov. 2015. Accepted for publication 16 Mar. 2016.

Partial funding was provided by the New Hampshire Agricultural Experiment Station. This is Scientific Contribution Number 2610. This work was supported by the USDA National Institute of Food and Agriculture (Hatch Project NH00548).

${ }^{1}$ Current address: Ken Olson Science Center, Gordon College, Wenham, MA 01924.

${ }^{2}$ Corresponding author. E-mail: james.loy@unh. edu. cultivar, but with small blossom scars and more rounded shoulders. The parents of 'Eclipse' are a bush inbred line, NH.Max6331, with a complex pedigree, and NH.Max5273, a vining inbred line derived from the $\mathrm{F}_{1}$ hybrid Kurijiman (Kyowa Seed Company, Japan). The parents of 'Thunder' are NH.Max5273 and a bush line, NH.Max2-12-11, developed before 1995. NH.Max6331 is one of the parents of 'Space Station', the other being a semibush line, NH.81110-2, developed from a complex pedigree. Three of the cultigens, NH.Max33-12 $\left(\mathrm{F}_{7}\right)$, NH.Max264 $\left(\mathrm{F}_{5}\right)$, and 'Sunshine', have orange rinds and carry the $B^{\max }$ gene (Paris and Brown, 2005) for precocious orange pigmentation of the fruit.

Plant culture. Plots were established at the Woodman Research Farm in Durham, $\mathrm{NH}$ (lat. $43^{\circ} \mathrm{N}$ ), or at the nearby Kingman Research Farm in Madbury, NH, in 2007, 2008, and 2009, using randomized complete block designs with three (2007 and 2009) or four (2008) replications and eight plants per plot. In 2008, the C. moschata cultigens and $C$. maxima breeding lines were grown in adjacent plots, and the C. maxima hybrids were grown in a separate field, and included additional hybrids not used in the present study. Plants were started from seed in 50-plug trays with Promix media (Premier Tech Horticulture, Quakertown, PA) and transplanted at the two true-leaf stage during the first week in June. Plants were grown on raised beds $(\approx 15 \mathrm{~cm}$ high $\times 60 \mathrm{~cm}$ wide $)$ covered with $31.8 \mu \mathrm{m}$ black polyethylene mulch, and with drip tape $(203.2 \mu \mathrm{m}$ T-tape with $30 \mathrm{~cm}$ emitter spacing; T-Systems International, San Diego, CA) laid at a depth of $\approx 3 \mathrm{~cm}$ slightly off the bed center. Bed centers were $2.1 \mathrm{~m}$ apart. Before bed formation, fertilizer was applied broadcast at the rate of $56 \mathrm{~kg} \cdot \mathrm{ha}^{-1}$ of $\mathrm{N}$ (calcium ammonium nitrate) and $\mathrm{K}$ (potassium chloride). Beginning $\approx 10 \mathrm{~d}$ before flowering, $5.6 \mathrm{~kg} \cdot \mathrm{ha}^{-1}$ of $\mathrm{N}$ and $4.7 \mathrm{~kg} \cdot \mathrm{ha}^{-1}$ of $\mathrm{K}$ were applied weekly through the drip tape for four or five consecutive weeks. Insect and disease control followed the recommendations given in the 2006-07 New England Vegetable Management Guide (Howell et al., 2007).

Harvesting and storage. Fruits were tagged at anthesis (opening of the flower) and harvested at either 40 or 60 DAP. Squash is considered mature when seed development is complete in terms of seed fill (Loy, 2004), typically $\approx 55$ DAP in temperate climates (Vining and Loy, 1998). One tagged fruit was harvested from each of four replications at 40 DAP for sampling, and 12 tagged fruits were harvested at $60 \mathrm{DAP}$ for sampling at 0 , 30 , and $60 \mathrm{~d}$ of storage at $14{ }^{\circ} \mathrm{C}$. Extra tagged fruit were harvested at $60 \mathrm{DAP}$ to account for possible fruit loss during storage. Fruits were weighed at harvest and after removal from storage to determine weight loss.

Sampling methods. Samples of C. moschata butternut squash were taken from the solid flesh in the neck region $\approx 2 \mathrm{~cm}$ proximal to the seed cavity. A $2 \mathrm{~cm}$ thick $\times 10 \mathrm{~cm}$ wide cross section of flesh was prepared by removing skin and cutting into eight smaller triangular samples.
Samples of $C$. maxima kabocha and $C$. moschata with round to oblate fruits were taken from the shoulder of the squash, about midway between the peduncle and equatorial region of the fruit opposite to the ground spot. The fibrous inner tissue was removed from the interior of the cross section. Two $10 \mathrm{~g}$ sections of squash were cut transversely into 20 rectangular cuboidal sections (lengthwise from outer to inner) and stored in poly bags and frozen immediately $\left(-80{ }^{\circ} \mathrm{C}\right)$. Preliminary analyses determined that samples prepared in this manner were uniform and representative of the carotenoid concentration in fruit mesocarp tissue (Bonina-Noseworthy, 2012).

Quantitative determination of total carotenoids. Because light can degrade carotenoids, ultraviolet-blocking film (Gila Film Products, Martinsville, VA) was used to cover laboratory windows and ultravioletblocking, clear plastic tubes were used to cover the fluorescent lights. Either amber glassware or glassware covered in aluminum foil was used during analyses to block light. Carotenoids were extracted from frozen $\left(-80^{\circ} \mathrm{C}\right)$ squash, using $1.0 \mathrm{~g}$ samples homogenized with $40 \mathrm{~mL}$ of HPLC grade acetone (Fisher Scientific, Pittsburgh, PA) for $4 \mathrm{~min}$ in an Omni-mixer (Sorvall Inc., Newtown, CT). The extracts were recovered by filtering through $0.5-\mathrm{mm}$ Whatman No. 1 filters (Fisher Scientific) using a Buchner funnel under vacuum. Carotenoids were extracted two more times $(40 \mathrm{~mL}$ fresh acetone per extraction) from the same tissue sample (110 $\mathrm{mL}$ final volume) until the tissue was colorless, resulting in $96 \%$ to $98 \%$ recovery of carotenoid pigments. The extracts were combined and absorbance at $450 \mathrm{~nm}$ determined in a Genesys 6, double-beam spectrophotometer (ThermoScientific, Pittsburgh, PA). For determining carotenoid concentrations, we used the following equations (Rodriguez-Amaya, 2001):

$$
\begin{gathered}
x(\mu \mathrm{g})=\text { absorbance } \cdot(y) 10^{6} / A_{1 \mathrm{~cm}}^{1 \%} \cdot 100 \\
x(\mu \mathrm{g} / \mathrm{g})=x(\mu \mathrm{g}) / \text { samples weight }
\end{gathered}
$$

where $x$ is the weight or concentration of carotenoid, $y$ is the volume of solution that gives an absorbance value at the specified wavelength, and $A^{1 \%}{ }_{1} \mathrm{~cm}$ is the absorption coefficient of the carotenoid(s) in the solvent solution. An absorption coefficient $\left(A^{1 \%}{ }_{1 \mathrm{~cm}}\right)$ of 2500 was used for the mixed carotenoid solutions (Britton, 1985).

High-performance liquid chromatography. Methodology similar to that described by Rodriguez-Amaya (2001) was used to prepare samples for HPLC analysis. Thirty $\mathrm{mL}$ aliquots were taken from the $110 \mathrm{~mL}$ carotenoid extracts used for the spectrophotometric total carotenoid determination. An internal standard, $50 \mu \mathrm{L}$ trans $\beta$-apo-8-carotenoate (Sigma-Aldrich, St. Louis, MO), was added to the $30 \mathrm{~mL}$ aliquots to estimate carotenoid losses during extraction and saponification. The $30-\mathrm{mL}$ samples were partitioned into $10 \mathrm{~mL}$ of petroleum ether in a separatory funnel and water was added slowly until the two 
phases separated. The lower aqueous/acetone layer was discarded and the upper layer was reserved. Water (15 $\mathrm{mL}$ aliquots) was added to the separatory funnel four to five times until the petroleum ether layer was bright yellow and the lower layer was colorless. To ensure all of the carotenoids were transferred to the petroleum ether layer, absorbance of the aqueous layer at $450 \mathrm{~nm}$ was measured spectrophotometrically. The samples were transferred to screw cap, $25-\mathrm{mL}$ glass tubes (Fisher Scientific). Samples were evaporated to dryness under a stream of nitrogen using a nitrogen evaporator (Organomation Inc, Berlin, MA) in a water bath at $35^{\circ} \mathrm{C}$, as described by Toomey and McGraw (2007).

Both saponified and unsaponified samples were analyzed by HPLC to obtain information on degree of esterification of xanthophylls. Samples were saponified by adding $10 \mathrm{~mL}$ of $5.6 \%$ methanolic $\mathrm{KOH}$ to glass tubes containing the dried carotenoids, capped, and allowed to stand overnight $(16 \mathrm{~h})$ at room temperature in darkness (Toomey and McGraw, 2007). A saturated sodium chloride solution was added to samples, followed by vigorous agitation by hand for $30 \mathrm{~s}$. Samples were then transferred to a separatory funnel containing $10 \mathrm{~mL}$ petroleum ether. Water was added slowly until the two phases separated. The upper organic layer was bright yellow and contained concentrated carotenoids. The lower aqueous layer also contained carotenoids but was faint yellow. The lower layer was collected and washed with water and $5 \mathrm{~mL}$ aliquots of petroleum ether until colorless (three to four times). All of the aliquots of carotenoids in petroleum ether were combined and evaporated to dryness under a stream of nitrogen. Samples were reconstituted in $3 \mathrm{~mL}$ acetone, to provide enough sample volume for both spectrophotometric determinations and HPLC analyses. To help solubilize carotenoids into acetone, samples were placed in vortex mixer (VWR Scientific Industry Inc., Bohemia, NY) for $30 \mathrm{~s}$ and then sonicated in an ultrasonic cleaner (Smith Kline Co., Shelton, CT) for $30 \mathrm{~s}$. One $\mathrm{mL}$ samples were transferred to $1.5 \mathrm{~mL}$-amber glass vials for storage before injection of a $20 \mu \mathrm{L}$ sample onto the HPLC column.

Carotenoid samples were analyzed using a Hewlett Packard/Agilent Technologies 1100 series HPLC system with a photodiode array detector (Agilent Technologies, Palo Alto, CA). A 5- $\mu \mathrm{m}, 200 \AA$ A polymeric $\mathrm{C}_{30}$ reverse-phase column (Pronto-SIL; MACMOD Analytical Inc, Chadds Ford, PA) was used to separate the analytes. The HPLC mobile phase solvent A consisted of methanol/ methyl tert-butyl ether (MTBE)/water (83:15:2, $\mathrm{v} / \mathrm{v} / \mathrm{v}$, with $1.5 \%$ ammonium acetate in the water); solvent B was methanol/MTBE/ water $(8: 90: 2, \mathrm{v} / \mathrm{v} / \mathrm{v}$, with $1 \%$ ammonium acetate in the water). The samples were processed by Agilent Chemstation software (Agilent Technologies, Santa Clara, CA). Concentrations were determined by comparison with a standard curve using pure carotenoid standards (Carotenature, Lupsingen, Switzerland).

Mass spectrometry analysis. Saponified samples of 'Sunshine' and 'Waltham Butternut' were sent to the Carotenoids and Health Laboratory at the Jean Mayer USDA Human Nutrition Research Center on Aging at Tufts University (Boston, MA) for analysis to identify major unknown peaks in the HPLC chromatograms using liquid chromatography-tandem mass spectrometry (LC-MS). LC-atmospheric pressure chemical ionization-MS analysis was performed with an Agilent LC-MS (Agilent Technologies) equipped with an Agilent HPLC autosampler, ultraviolet detector, HP1100, MSD with APCI interface, and a $\mathrm{C}_{30}$ column $[3 \mathrm{~mm}$, $150 \mathrm{~mm} \times 4.6 \mathrm{~mm}$ (Bischoff Chromatography, Leonberg, Germany)]. The HPLC mobile phase A contained methanol, MTBE, and $1.5 \%$ ammonium acetate in water $(83: 15: 2$, $\mathrm{v} / \mathrm{v} / \mathrm{v})$; and phase B contained methanol, MTBE, and $1.0 \%$ ammonium acetate in water $(8: 90: 2, \mathrm{v} / \mathrm{v} / \mathrm{v})$. Gradient procedures (flow rate $1 \mathrm{~mL} / \mathrm{min}$ ) were changed as follows: $0 \% \mathrm{~B}$ isocratic $(0-2 \mathrm{~min}), 0 \% \mathrm{~B}-5 \%$ B linear gradient (2-10 min), 5\% B-55\% B linear gradient $(10-18 \mathrm{~min}), 55 \% \mathrm{~B}-95 \%$ B linear gradient (18-20 min), 95\% B- $0 \%$ B linear gradient $(20-21 \mathrm{~min})$, and $0 \% \mathrm{~B}$ isocratic (21-40 $\mathrm{min})$. The injection volume was $20 \mu \mathrm{L}$ and the total run time was $40 \mathrm{~min}$. The ultraviolet-visible spectra of peaks were recorded in the range of $250-600 \mathrm{~nm}$ and the mass spectra were recorded using the following parameters: polarity, positive; mass range, m/z 530-630; fragmentor, 90; gain, 20.00; threshold, 150; and stepsize, 0.1. Data acquisition and processing were performed using ChemStations software (Agilent Technologies).

Saponified samples of 'Sunshine' and 'Waltham Butternut' were also sent to the carotenoid laboratory of Dr. Dean Kopsell, University of Tennessee, for separation on a $\mathrm{C}_{30}$ column that employed different mobile phase solvents and gradients for separating carotenoid pigments than used at UNH (Kopsell et al., 2007). This permitted analysis of peak carotenoid retention times (RT) of samples and known carotenoids under different conditions of separation. Separations in Kopsell's laboratory were achieved isocratically using a binary mobile phase of $11 \% \mathrm{MTBE}$, $88.9 \mathrm{MeOH}$, and $0.1 \%$ triethylamine $(\mathrm{v} / \mathrm{v})$. The flow rate was $1.0 \mathrm{~mL} / \mathrm{min}$, with a run time of $53 \mathrm{~min}$, followed by a $10 \mathrm{~min}$ equilibration before the next injection (Kopsell et al., 2007).

Statistical analysis. Analysis of variance and Tukey's honestly significant difference multiple means test were used to compare main effects of cultigen, storage length, and year on carotenoid concentrations, using either JMP, Version 9 (SAS Institute Inc., Cary, NC) or Microsoft Excel statistical tools (Microsoft Corporation, Redman, WA).

\section{Results and Discussion}

Carotenoids and squash maturity at harvest. In the present study, kabocha (C. maxima) fruit appeared mature at 40 DAP in terms of skin color; however, the carotenoid concentration of intact fruit increased by $81 \%$ in the C. maxima inbred line NH.Max6331 between 40 and 60 DAP (Table 1). The range of carotenoid concentrations in four inbred lines of C. maxima squash was 177 to 214 $\mu \mathrm{g} \cdot \mathrm{g}^{-1} \mathrm{FW}$ at $40 \mathrm{DAP}$, and increased to 222 to $320 \mu \mathrm{g} \cdot \mathrm{g}^{-1} \mathrm{FW}$ by 60 DAP (Table 1 ). Differences in mean carotenoid concentration among the four inbred lines at the two harvest dates were not statistically significant. In a New Zealand study, the carotenoid concentrations in three kabocha hybrids sampled at $49 \mathrm{~d}$ after fruit set ranged from 91 to $152 \mu \mathrm{g} \cdot \mathrm{g}^{-1} \mathrm{FW}$, with a value of 115 $\mu \mathrm{g} \cdot \mathrm{g}^{-1} \mathrm{FW}$ for the widely grown kabocha hybrid 'Delica' (Hurst et al., 1995).

'Sunshine' and the inbred lines NH.Max3312 and NH.Max264 are homozygous for the " $B$ max" gene for precocious orange rind color. In $C$. pepo, the " $B$ " gene elevates carotenoid concentrations of fruit in some genetic backgrounds by as much as 6-fold (Schaffer et al., 1986; Tadmoor et al., 2005). In our study, the $C$. maxima cultigens with the " $B^{\max }$ " gene did not display higher carotenoid concentrations than the other inbred lines and hybrids (Tables 1 and 2).

In C. moschata, mean carotenoid concentrations in fruit of all cultigens harvested at $60 \mathrm{DAP}$ were $30 \%$ to $100 \%$ higher than in fruit harvested at 40 DAP (Table 1). It was difficult to discern differences in fruit maturity in the tan butternuts harvested at 40 and 60 DAP based on fruit color. However, in a study by Zaccari and Galietta (2015), three maturity dates in the butternut $F_{1}$ hybrid 'Cosmo' could be discerned, based on changes in green pigmentation of peduncles and peeled skin color, and they reported progressive increases in $\alpha$-carotene and $\beta$-carotene at the three maturity periods from immature to very mature.

There were significant differences in carotenoid concentration among the $C$. moschata cultigens, and the differences were more accentuated in fruit harvested at 60 DAP than in fruit harvested at $40 \mathrm{DAP}$. Concentrations varied from a low value of $42 \mu \mathrm{g} \cdot \mathrm{g}^{-1} \mathrm{FW}$ in NHBBN to $145 \mu \mathrm{g} \cdot \mathrm{g}^{-1} \mathrm{FW}$ in NH.Mo851, a small, round-fruited, breeding line with green skin (Table 1).

Carotenoids and storage. Total carotenoids increased linearly between 0 and $60 \mathrm{~d}$ of storage in two (NH.Max6331 and NH.Max3312) of the four $C$. maxima inbreds, but the magnitude of change was different between the two cultigens (Table 2). In NH.Max6331, carotenoid concentration doubled from $320 \mu \mathrm{g} \cdot \mathrm{g}^{-1} \mathrm{FW}$ at $0 \mathrm{~d}$ to $639 \mu \mathrm{g} \cdot \mathrm{g}^{-1} \mathrm{FW}$ after $60 \mathrm{~d}$ of storage; whereas, in NH.Max33-12 the carotenoid concentration increased by $\approx 50 \%$. NH.Max5273 did not show a statistically significant increase. Although there was an apparent reduction in total carotenoids in NH.Max 264 between 30 and $60 \mathrm{~d}$ of storage, there was considerable variability among replications and the differences were not statistically significant.

Among the $C$. moschata cultigens, either most increases in carotenoid concentration 
Table 1. Comparison of total carotenoid concentrations determined spectrophotometrically in fruit samples of Cucurbita maxima inbred lines and Cucurbita moschata cultivars and inbred lines, harvested either at 40 or 60 DAP in 2008.

\begin{tabular}{|c|c|c|c|c|c|c|c|}
\hline \multicolumn{4}{|c|}{ Total carotenoids $\left(\mu \mathrm{g} \cdot \mathrm{g}^{-1} \mathrm{FW}\right)$} & \multicolumn{4}{|c|}{ Total carotenoids $\left(\mu \mathrm{g} \cdot \mathrm{g}^{-1} \mathrm{FW}\right)$} \\
\hline C. maxima & 40 DAP & 60 DAP & $\mathrm{ANOVA}^{\mathrm{z}}$ & C. moschata & 40 DAP & 60 DAP & $\mathrm{ANOVA}^{2}$ \\
\hline NH.Max5273 & $192 \mathrm{a}$ & $250 \mathrm{a}$ & NS & $\mathrm{PBN}^{\mathrm{x}}$ & $47 \mathrm{ab}$ & $61 \mathrm{ab}$ & 0.023 \\
\hline \multirow[t]{4}{*}{ NH264 } & $214 \mathrm{a}$ & $256 \mathrm{a}$ & NS & NH.Mo2521 & $59 \mathrm{abc}$ & $82 \mathrm{~b}$ & NS \\
\hline & & & & NH.Mo910 & $73 \mathrm{bc}$ & $121 \mathrm{c}$ & NS \\
\hline & & & & NH.Mo421 & $88 \mathrm{c}$ & $133 \mathrm{c}$ & 0.0001 \\
\hline & & & & NH.Mo851 & $87 \mathrm{c}$ & $145 \mathrm{c}$ & 0.038 \\
\hline
\end{tabular}

${ }_{\mathrm{z}_{\mathrm{NS}}}=$ nonsignificant differences in carotenoid content by harvest date according to ANOVA.

${ }^{y}$ Mean values in columns denoted by the same letter are not significantly different, Tukey's honestly significant difference test at $P \leq 0.05$.

${ }^{x} \mathrm{NHBBN}=$ 'New Hampshire Baby Butternut'; PBN = 'Puritan Butternut'; and WBN = 'Waltham Butternut'.

$\mathrm{DAP}=$ days after pollination; ANOVA $=$ analysis of variance.

Table 2. Comparison of total carotenoid concentrations determined spectrophotometrically in fruit samples of Cucurbita maxima and Cucurbita moschata cultigens harvested $60 \mathrm{~d}$ after pollination in 2008 and stored for either 0,30 or $60 \mathrm{~d}$ at $14{ }^{\circ} \mathrm{C}$.

\begin{tabular}{|c|c|c|c|c|c|c|c|c|c|}
\hline \multicolumn{5}{|c|}{ Total carotenoids $\left(\mu \mathrm{g} \cdot \mathrm{g}^{-1} \mathrm{FW}\right)$} & \multicolumn{5}{|c|}{ Total carotenoids $\left(\mu \mathrm{g} \cdot \mathrm{g}^{-1} \mathrm{FW}\right)$} \\
\hline C. maxima & 0 & 30 & 60 & ANOVA $^{z}$ & C. moschata & 0 & 30 & 60 & ANOVA \\
\hline $\operatorname{Max} 5273$ & $250 \mathrm{a}$ & $308 \mathrm{a}$ & $259 \mathrm{ab}$ & NS & PBN & $61 \mathrm{ab}$ & $101 \mathrm{~b}$ & $123 \mathrm{~b}$ & 0.001 \\
\hline & & & & & NH.Mo910 & $121 \mathrm{c}$ & $156 \mathrm{c}$ & $187 \mathrm{c}$ & 0.001 \\
\hline & & & & & NH.Mo851 & $145 \mathrm{c}$ & $187 \mathrm{~cd}$ & $186 \mathrm{c}$ & 0.041 \\
\hline & & & & & NH.Mo421 & $133 \mathrm{c}$ & $211 \mathrm{~d}$ & $227 \mathrm{c}$ & 0.028 \\
\hline
\end{tabular}

${ }^{2} \mathrm{NS}=$ nonsignificant differences in carotenoid content by harvest date according to ANOVA.

y Mean values in columns denoted by the same letter are not significantly different by Tukey's honestly significant difference test at $P \leq 0.05$.

${ }^{x}$ Mean values of NH.Max264 and NH.Max6331 at 30 and $60 \mathrm{~d}$ were adjusted for missing data.

NHBBN = 'New Hampshire Baby Butternut'; PBN = 'Puritan Butternut'; and WBN = 'Waltham Butternut'.

ANOVA $=$ analysis of variance.

occurred during storage of fruit for the first $30 \mathrm{~d}$ or carotenoid concentration increased more or less linearly to a maximum at 60 DAP (Table 2). The three C. moschata cultigens with the highest carotenoid concentrations at harvest also had the highest concentrations after $60 \mathrm{~d}$ of storage. The largest increase occurred in NH.Mo421, from $133 \mu \mathrm{g} \cdot \mathrm{g}^{-1} \mathrm{FW}$ at $0 \mathrm{~d}$ storage to $239 \mu \mathrm{g} \cdot \mathrm{g}^{-1}$ FW after 60-d storage. Our results are consistent with those of previous investigators showing that carotenoid concentration increases during storage in most squash and pumpkin cultigens, but that the magnitude of change differs among cultigens, as does the length of storage time required for maximizing carotenoid concentration (ArvayoOrtiz et al., 1994; Harvey et al., 1997; Hopp et al., 1960). From a nutritional viewpoint, it would be important in plant improvement to search for genotypes which exhibit substantial postharvest increases in carotenoid concentration.

We compared carotenoid concentrations in our study on a FW basis, but the relative differences in carotenoid contents among cultigens and the changes with storage time within species were similar whether based on dry weight (DW) or FW (data not shown; see Bonina-Noseworthy, 2012). However, because the average DW of mesocarp tissue for kabocha cultivars was $29 \%$ as compared with $19 \%$ for the seven C. moschata cultigens in fruit harvested at 60 DAP, carotenoid concentrations of $C$. moschata cultigens were elevated relative to those of $C$. maxima when expressed on a DW basis (Bonina-Noseworthy, 2012). For nutritional comparisons, carotenoids are generally compared on a FW basis because such values can be related directly to food consumption (Britton and Khachik, 2009; Khachik, 2009). Storage of squash results in an appreciable reduction in FW, both because of water loss and conversion of sugars to $\mathrm{CO}_{2}$ during respiration (Bonina-Noseworthy, 2012; Corrigan et al., 2001; Irving et al., 1997). The average FW loss in the four C. maxima inbred lines and the hybrid 'Sunshine' during 60-d storage was $8.6 \%$; the average $\mathrm{FW}$ loss in the seven $C$. moschata cultigens was appreciably higher $(15.1 \%)$. We did not determine the degree to which weight loss was accompanied by a reduction in fruit volume. Carotenoid concentrations in several cultigens did not change significantly between 30 and $60 \mathrm{~d}$ of storage, suggesting that changes in fruit weight had minimal impact on carotenoid concentrations.

Characterization of carotenoid profiles. Along with knowledge of carotenoids previously identified in squash and pumpkin (Azevedo-Meleiro and Rodriguez-Amaya, 2007; Khachik et al., 1988; Khachik and Beecher, 1988), the major peaks in the HPLC chromatograms were identified by comparing peak RT with RT of known standards, comparing RT with HPLC obtained on a $\mathrm{C}_{30}$ column at the UNH with those obtained on a $\mathrm{C}_{30}$ column at the University of Tennessee, and obtaining the molecular ion mass $\left(\mathrm{M}^{+}\right)$for unknown major peaks by HPLC coupled with mass spectrometry (Carotenoids and Health
Laboratory at the Jean Mayer USDA Human Nutrition).

Nonesterified carotenoids exhibited RT between 5 and 21 min (Figs. 1A and 2B), but in unsaponified samples (Figs. 1B and 2B), there were numerous minor peaks mostly with RT greater than $21 \mathrm{~min}$, representing esterified carotenoids. In saponified samples of C. $\max$ ima, there were five major carotenoid peaks tentatively identified, listed according to their order with HPLC (Fig. 1A): 1) neoxanthin, 2) flavoxanthin, 4) lutein, 5) zeaxanthin, and 8) $\beta$-carotene. Peak 6 was the internal standard, $\beta$-apo- 8 -carotenoate. Peaks 4,5 , and 8 were coincident, respectively, with peaks for the known standards, lutein, zeaxanthin, and $\beta$-carotene. Peak 1 was suspected to be neoxanthin, based on its short RT and previous identification in both $C$. maxima and $C$. moschata (Azevedo-Meleiro and RodriguezAmaya, 2007). In a carotenoid extract of 'Sunshine' analyzed at University of Tennessee, the putative neoxanthin peak had the same RT (5.4) as a known neoxanthin sample. Mass spectrometry also showed a peak molecular mass ion of $601 / 602$ for peak 1 , corresponding to that expected for neoxanthin (Moss and Weedon, 1976; de Rosso and Mercandante, 2007). The molecular ion peak $\left(\mathrm{M}^{+}\right)$of $585 / 586$ for peak 2 corresponded to the molecular ion peak $(\mathrm{M}+\mathrm{H})^{+}$of 585 for flavoxanthin (lutein 5,8 -epoxide), previously identified in a processing cultigen of $C$. maxima by Khachik and Beecher (1988). The designation of flavoxanthin is tentative because lutein 5,6-epoxide has the same mass as flavoxanthin (de Rosso and 

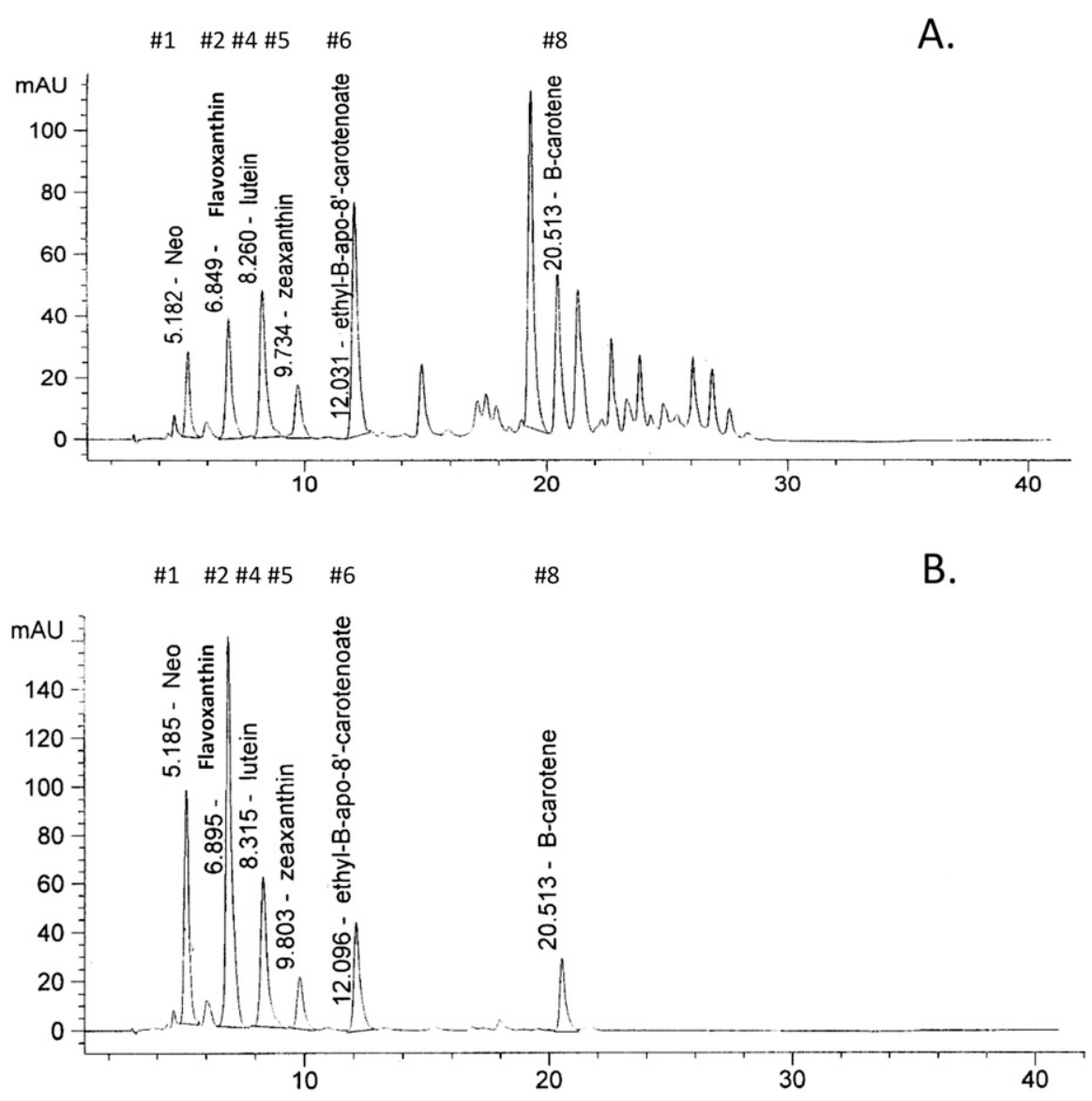

Fig. 1. Typical high-performance liquid chromatography carotenoid chromatograms in Cucurbita maxima from (A) unsaponified and (B) saponified squash extracts. Example is for kabocha cultivar Space Station. Neo, peak \#1, is abbreviation for neoxanthin.

Mercandante, 2007; Moss and Weedon, 1976), but is most often associated with leafy tissue (Kopsell and Kopsell, 2006). Peak 5 was tentatively labeled as zeaxanthin based on RT correspondence with a known zeaxanthin sample. Likewise, a carotenoid extract of 'Sunshine' analyzed by HPLC at University of Tennessee exhibited the same RT (10.9) as a known sample of zeaxanthin.

In saponified samples of C. moschata, five major carotenoid peaks were typically present in all cultigens (Fig. 2A): 1) neoxanthin, 3) violaxanthin, 4) lutein, 7) $\alpha$-carotene, and 8) $\beta$-carotene. Peak 1 was tentatively identified as neoxanthin as discussed above. Peak 3 (RT 7.4) is likely violaxanthin, based on a $\mathrm{M}^{+}$ peak of $600 / 601$ corresponding to values obtained by Khachik et al. (1988) and de Rosso and Mercandante (2007). In addition, the RT (4.9) for the putative violaxanthin peak in a sample of 'Waltham Butternut' analyzed on $\mathrm{C}_{30}$ column at the University of Tennessee corresponded to the RT for a known sample of violaxanthin. The RT for peaks 7 (RT 19.0) and 8 (RT 20.7) in Fig. 2A corresponded, respectively, with those of known samples of $\alpha$-carotene and $\beta$-carotene.

HPLC was performed on both unsaponified and saponified samples to allow for comparison of the degree of esterification of hydroxyl carotenoids as well as for determining the extent of carotenoid loss resulting from saponification. There was considerable variability in the degree of esterification between species and among cultigens (Table 3 ). In general, the degree of esterification was higher in cultigens of C. moschata than those of C. maxima, and in three of the four $C$. moschata cultigens, the proportion of esterified carotenoids among the three xanthophylls was usually greater than 0.9 . However, in NH.Mo851 only a relatively small proportion $(0.22)$ of lutein was esterified. High proportions of free, nonesterified, lutein have not been previously reported in $C$. moschata, and cultigens with this trait may be a promising source for pharmaceutical firms producing supplements as an alternative to the main source of lutein is currently obtained from saponified extracts of marigold flowers (Amala-Sujith et al., 2010).

In C. maxima, variability in proportion of esterification among the four xanthophylls ranged from low values of 0.05 for zeaxanthin and 0.21 for flavoxanthin in 'Sunshine' to a high value of 0.69 for flavoxanthin in 'Space Station' (Table 3). The proportion of esterified lutein in C. maxima varied from a low of 0.12 in 'Sunshine' to a high of 0.42 in 'Space Station'. Esterification of hydroxyl carotenoids in the different species of squash have been previously well documented, and xanthophylls shown to be esterified to lauric, myristic, and palmitic fatty acids (Khachik et al., 1988; Khachik and Beecher, 1988).

Carotenoid esters are largely absent in human plasma and organs (Canene-Adams and Erdman, 2009; Khachik, 2009). Because esterified carotenoids lutein and zeaxanthin must be hydrolyzed to the free form before absorption, the degree of esterification in carotenoid sources could impact their nutritional status. Studies to date, however, indicate that esterified forms of lutein and zeaxanthin are as bioavailable as the free form (Bowen et al., 2002; Breithaupt et al., 2004).

Variability in $\alpha$-carotene and $\beta$-carotene among cultigens. $\beta$-Carotene concentrations were moderately high in $C$. maxima (Table 4), and although mean concentrations varied from 26.0 to $44.1 \mu \mathrm{g} \cdot \mathrm{g}^{-1} \mathrm{FW}$ among the hybrids, the differences were not statistically significant. Comparatively low concentrations of $\beta$-carotene ( 3.0 to $8.7 \mu \mathrm{g} \cdot \mathrm{g}^{-1} \mathrm{FW}$ ) were reported in two baby food cultivars of $C$ maxima (Khachik and Beecher, 1988); whereas, a considerably broader range of concentrations, from 14 to $74 \mu \mathrm{g} \cdot \mathrm{g}^{-1} \mathrm{FW}$, were reported for 12 cultivars of $C$. maxima (Murkovic et al., 2002). $\alpha$-Carotene was detected in only trace amounts in C. maxima hybrids (Fig. 1B), but has been found in moderate amounts in some cultivars (Murkovic et al., 2002).

$\alpha$-Carotene was detected in some $C$. moschata cultigens, but in low amounts, $6.1 \mu \mathrm{g} \cdot \mathrm{g}^{-1} \mathrm{FW}$ or lower (Table 4). Although $\alpha$-carotene concentrations are generally low in C. moschata cultigens, in a Brazilian cultivar, Brasileirinha, selected for high carotenoid content, $\alpha$-carotene concentrations averaged $82 \mu \mathrm{g} \cdot \mathrm{g}^{-1} \mathrm{FW}$ in mature squash (Boiteux et al., 2007), and $73 \mu \mathrm{g} \cdot \mathrm{g}^{-1}$ FW was reported in a Brazilian landrace (de Carvalho et al., 2012). In our study, there was wide variability in $\beta$-carotene concentrations in C. moschata, ranging from $17.6 \mu \mathrm{g} \cdot \mathrm{g}^{-1} \mathrm{FW}$ in 'Waltham Butternut' to $114.2 \mu \mathrm{g} \cdot \mathrm{g}^{-1} \mathrm{FW}$ in the inbred line NH.Mo421 at 60 DAP. Exceedingly high concentrations of $\beta$-carotene concentrations have been reported in Brazilian pumpkin cultigens with values of $244 \mu \mathrm{g} \cdot \mathrm{g}^{-1}$ FW reported in a landrace (de Carvalho et al., 2012) and $161 \mu \mathrm{g} \cdot \mathrm{g}^{-1} \mathrm{FW}$ in the cultivar Brasileirinha mentioned above (Boiteux et al., 2007). Among three North American butternut cultivars grown in Florida, Itle and Kabelka (2009) reported low concentrations of $\beta$-carotene, ranging from $2.1 \mu \mathrm{g} \cdot \mathrm{g}^{-1} \mathrm{FW}$ in 'Ponca' to $15.3 \mu \mathrm{g} \cdot \mathrm{g}^{-1} \mathrm{FW}$ for 'Butterbush'. However, our value of $17.3 \mu \mathrm{g}^{-1} \mathrm{~g}^{-1} \mathrm{FW}$ for 'Waltham Butternut' at DAP was considerably higher than that reported in Florida $\left(3.8 \mu \mathrm{g} \cdot \mathrm{g}^{-1}\right.$ FW). NH.Mo421 not only had a high concentration of $\beta$-carotene $\left(114 \mu \mathrm{g} \cdot \mathrm{g}^{-1} \mathrm{FW}\right)$, but also the proportion of $\beta$-carotene to total carotenoids $(67 \%)$ was higher than in the other cultigens evaluated, and the proportion of nutritionally important to total carotenoids was also high (83\%; Table 4).

Lutein and zeaxanthin concentrations among cultigens. Although the C. maxima squash evaluated for carotenoid profiles in 

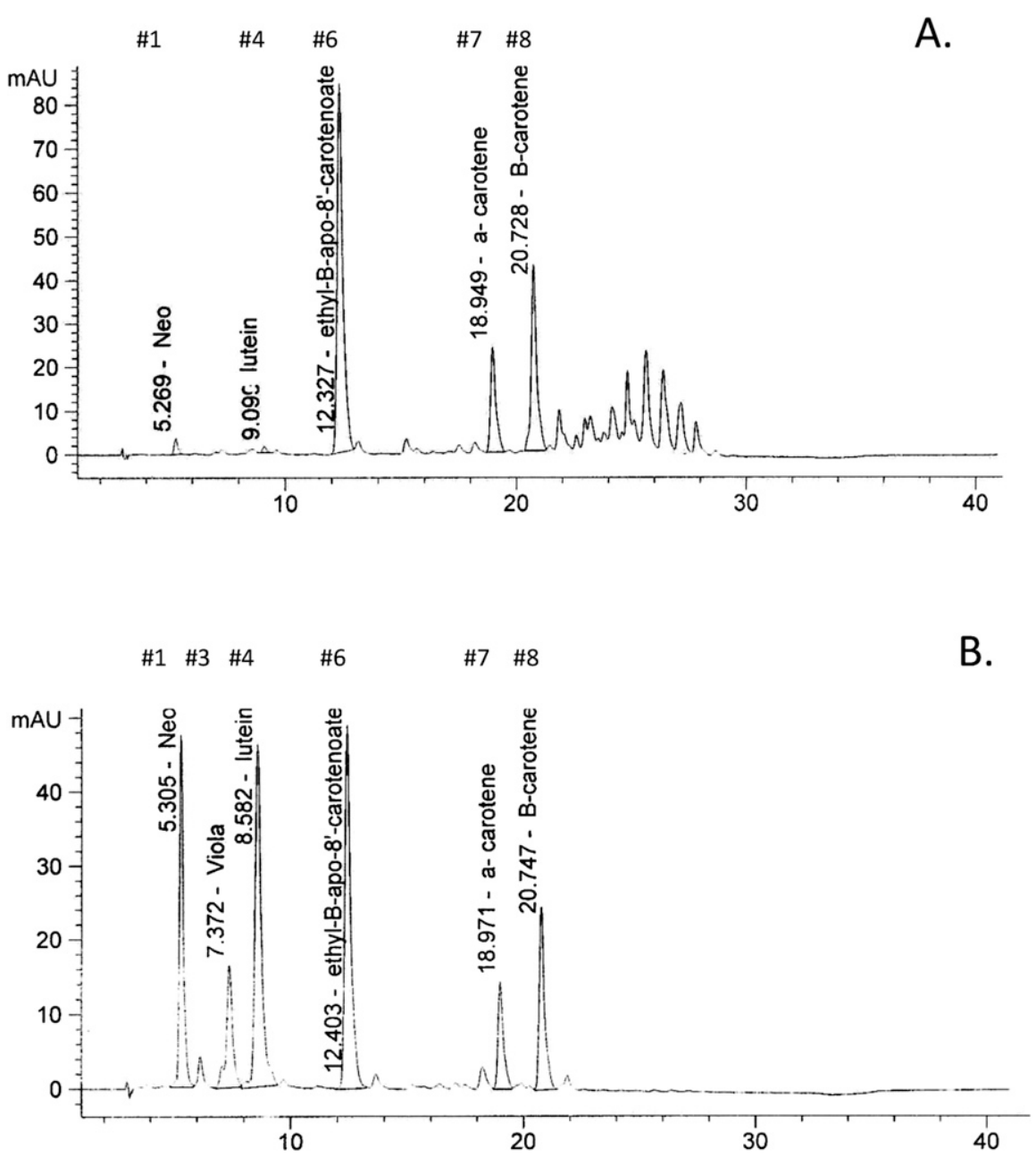

Fig. 2. Typical high-performance liquid chromatography carotenoid chromatograms in Cucurbita moschata of (A) unsaponified and (B) saponified squash extracts. Example is for 'Waltham Butternut'. Neo, peak \#1, is abbreviation for neoxanthin; viola, peak \#3, is abbreviation for violaxanthin.

Table 3. Proportion of esterified xanthophyll carotenoids in cultigens of Cucurbita maxima and Cucurbita moschata winter squash harvested at $60 \mathrm{~d}$ after pollination in 2008 , based on comparison of carotenoid concentrations of saponified and unsaponified samples separated by high-performance liquid chromatography.

\begin{tabular}{lcccc}
\hline Cultigens & \multicolumn{4}{c}{ Proportion of esterified carotenoids ${ }^{\mathrm{z}}$} \\
\hline C. maxima & Neoxanthin & Flavoxanthin & Lutein & Zeaxanthin \\
'Sunshine' & 0.06 & 0.21 & 0.12 & 0.05 \\
'Space station' & 0.59 & 0.69 & 0.42 & 0.50 \\
'Thunder' & 0.23 & 0.14 & 0.25 & 0.60 \\
'Eclipse' & 0.52 & 0.67 & 0.33 & 0.17 \\
C. moschata & Neoxanthin & Violaxanthin & Lutein & \\
WBN & 0.91 & 1.00 & 0.96 & \\
NH.Mo851 & 0.29 & 0.50 & 0.22 & \\
NH.Mo910 & 0.53 & 0.99 & 0.89 & \\
NH.Mo421 & 0.87 & 0.98 & 0.99 & \\
\hline
\end{tabular}

${ }^{2}$ Proportions based on four replications of saponified and unsaponified extracts. Values were adjusted for loss during extraction using an internal standard $\beta$-apo-8-carotenoate.

WBN $=$ 'Waltham Butternut'

this study were $F_{1}$ hybrids that had genetically diverse parentage, lutein concentrations among hybrids were fairly uniform and averaged $46.1 \mu \mathrm{g} \cdot \mathrm{g}^{-1} \mathrm{FW}$ (Table 4). In contrast, Murkovic et al. (2002) reported a wide range of lutein concentrations in 12 C. maxima cultivars, from as low as $8 \mu \mathrm{g} \cdot \mathrm{g}^{-1}$ FW to as high as $170 \mu \mathrm{g} \cdot \mathrm{g}^{-1} \mathrm{FW}$ in the cultivar Hyvita. Extracts were not saponified in the study by Murkovic et al. (2002), and as such, the high value for lutein in 'Hyvita' suggests that the proportion of esterified lutein may have been low in that cultivar.

In $C$. moschata, there was a relatively broad range of lutein concentrations among the four cultigens analyzed (Table 4). Concentrations at 60 DAP were highest in the breeding line NH.Mo $851\left(59.9 \mu \mathrm{g} \cdot \mathrm{g}^{-1} \mathrm{FW}\right)$, intermediate in NH.Mo910 (37 $\mu \mathrm{g} \cdot \mathrm{g}^{-1} \mathrm{FW}$ ), and lowest in 'Waltham Butternut' (27.3 $\mu \mathrm{g} \cdot \mathrm{g}^{-1} \mathrm{FW}$ ) and NH.Mo 421 (22.3 $\mu \mathrm{g} \cdot \mathrm{g}^{-1}$ FW). In the three butternut cultivars analyzed by Itle and Kabelka (2009), lutein concentrations ranged from a low of $8.7 \mu \mathrm{g} \cdot \mathrm{g}^{-1} \mathrm{FW}$ in 'Ponca' butternut to $17.3 \mu \mathrm{g} \cdot \mathrm{g}^{-1} \mathrm{FW}$ in WBN. In the study by Murkovic et al. (2002), concentrations of lutein + zeaxanthin were only $0.8 \mu \mathrm{g} \cdot \mathrm{g}^{-1} \mathrm{FW}$ for 'Butterbush' and $1.4 \mu \mathrm{g} \cdot \mathrm{g}^{-1} \mathrm{FW}$ for Long Island Cheese, the low values probably reflecting a high degree of esterification in the unsaponified samples. Neither of the preceding cultivars is widely grown in North America.

The carotenoid identified as zeaxanthin (peak 5; Fig. 1A) was detected in all $C$. maxima hybrids, with substantial amounts, $22 \mu \mathrm{g} \cdot \mathrm{g}^{-1} \mathrm{FW}$ and $25.2 \mu \mathrm{g} \cdot \mathrm{g}^{-1} \mathrm{FW}$, respectively, in 'Sunshine' and 'Thunder' (Table 4). Only minor amounts of zeaxanthin have been reported previously in C. maxima (Arima and Rodriguez-Amaya, 1988; Provesi, et al., 2011). Although we did not detect zeaxanthin in the C. moschata cultigens we analyzed, Humphries and Khachik (2003) reported the detection of appreciable amounts of zeaxanthin in an unknown butternut cultivar.

Concentrations of carotenoids not known to have nutritional benefits. Neoxanthin and flavoxanthin comprised between $38 \%$ and $59 \%$ of the total carotenoid profile in the $C$. maxima hybrids at 60 DAP (Table 4). Neoxanthin concentrations varied from a low of $16.8 \mu \mathrm{g} \cdot \mathrm{g}^{-1} \mathrm{FW}$ in 'Sunshine' to as high as $57.6 \mu \mathrm{g} \cdot \mathrm{g}^{-1} \mathrm{FW}$ in 'Space Station'. The range of flavoxanthin was even greater, varying from $50 \mu \mathrm{g} \cdot \mathrm{g}^{-1} \mathrm{FW}$ in 'Sunshine' to 102 $\mu \mathrm{g} \cdot \mathrm{g}^{-1} \mathrm{FW}$ in 'Space Station'. Neither of the above carotenoids are found in blood plasma (Khachik, 2009) or other organs (CaneneAdams and Erdman, 2009), and are currently not known to play a role in human nutrition. Neoxanthin was previously shown to comprise $20 \%$ of the total carotenoid concentration in a Brazilian C. maxima squash cultivar (Azevedo-Meleiro and Rodriguez-Amaya, 2007). The abundance of flavoxanthin in $C$. maxima kabocha hybrids appreciably lowered the ratio of nutritionally important carotenoids ( $\beta$-carotene, lutein, and zeaxanthin) to total carotenoids (Table 4).

In the $C$. moschata cultigens, neoxanthin comprised between $6 \%$ and $21 \%$ of total carotenoid profiles; whereas, violaxanthin was low ( 9 to $11 \mu \mathrm{g} \cdot \mathrm{g}^{-1} \mathrm{FW}$ ) among all four cultigens (Table 4). Neoxanthin was significantly higher in NH.Mo851 $\left(27.5 \mu \mathrm{g} \cdot \mathrm{g}^{-1} \mathrm{FW}\right)$ and NH.Mo421 (21.7 $\left.\mu \mathrm{g} \cdot \mathrm{g}^{-1} \mathrm{FW}\right)$ than in NH.Mo910 (5.9 $\left.\mu \mathrm{g} \cdot \mathrm{g}^{-1} \mathrm{FW}\right)$ and 'Waltham Butternut' $\left(7.4 \mu \mathrm{g} \cdot \mathrm{g}^{-1} \mathrm{FW}\right)$. Neoxanthin and violaxanthin were previously identified in C. moschata squash (Azevedo-Meleiro and Rodriguez-Amaya, 2007; González et al., 2001). Even though the contribution of neoxanthin and violaxanthin to human nutrition remains unknown, these two carotenoids have an important connection to plant hormone physiology. Neoxanthin and violoxanthin are cleaved to form abscisic acid (ABA), which plays roles in fruit ripening and seed 
Table 4. Carotenoid profiles of saponified extracts of Cucurbita maxima $\mathrm{F}_{1}$ hybrids and Cucurbita moschata inbred lines and the cultivar Waltham Butternut (WBN) harvested at $60 \mathrm{~d}$ after pollination in 2008, with separation and quantification by high-performance liquid chromatography analysis.

\begin{tabular}{|c|c|c|c|c|c|c|c|c|c|c|}
\hline \multicolumn{5}{|c|}{ Other major carotenoids $\left(\mu \mathrm{g} \cdot \mathrm{g}^{-1} \mathrm{FW}\right)^{\mathrm{z}}$} & \multicolumn{6}{|c|}{ Nutritionally important carotenoids $\left(\mu \mathrm{g} \cdot \mathrm{g}^{-1} \mathrm{FW}\right)^{\mathrm{z}}$} \\
\hline Cultigens & Neoxanthin & Flavoxanthin & Violaxanthin & Total & Lutein & Zeaxanthin & $\alpha$-Carotene & $\beta$-Carotene & Total & BLZ/total \\
\hline 'Sunshine' & $16.8 \mathrm{a}^{\mathrm{x}}$ & $33.2 \mathrm{a}$ & 0 & $50.0 \mathrm{a}$ & $36.8 \mathrm{a}^{\mathrm{x}}$ & $22.0 \mathrm{a}$ & 0 & $26.0 \mathrm{a}$ & $84.8 \mathrm{a}$ & 0.63 \\
\hline 'Eclipse' & $22.8 \mathrm{a}$ & $81.7 \mathrm{bc}$ & 0 & $104.5 \mathrm{~b}$ & $49.9 \mathrm{a}$ & $9.9 \mathrm{a}$ & 0 & $37.1 \mathrm{a}$ & $96.9 \mathrm{a}$ & 0.48 \\
\hline 'Space Station' & $57.6 \mathrm{~b}$ & $102.1 \mathrm{c}$ & 0 & $159.7 \mathrm{c}$ & $59.5 \mathrm{a}$ & $15.9 \mathrm{a}$ & 0 & $32.7 \mathrm{a}$ & $108.1 \mathrm{a}$ & 0.41 \\
\hline \multicolumn{11}{|l|}{ C. moschata } \\
\hline 'Waltham BN' & $13.4 \mathrm{a}^{\mathrm{x}}$ & 0 & $11.0 \mathrm{a}$ & $24.4 \mathrm{a}$ & $27.3 \mathrm{ab}^{\mathrm{x}}$ & 0 & $0.8 \mathrm{a}$ & $17.6 \mathrm{a}$ & $45.7 \mathrm{a}$ & 0.65 \\
\hline NH.Mo421 & $21.7 \mathrm{~b}$ & 0 & $9.3 \mathrm{a}$ & $31.0 \mathrm{~b}$ & $22.3 \mathrm{a}$ & 0 & $4.5 \mathrm{a}$ & $114.2 \mathrm{a}$ & $141.0 \mathrm{c}$ & 0.83 \\
\hline
\end{tabular}

${ }^{\mathrm{z}}$ Values were adjusted for loss during saponification and extraction using an internal standard $\beta$-apo-8-carotenoate.

${ }^{\mathrm{y}} \mathrm{BLZ} /$ total equals ratio of nutritionally important carotenoids, $\beta$-carotene, lutein, and zeaxanthin (BLZ), to total carotenoids in profile.

${ }^{\mathrm{x}}$ Means within columns followed by the same letter are not significantly different by Tukey's honestly significant difference test at $P \leq 0.05$.

Table 5. Yearly comparison of carotenoid profiles of saponified extracts of 'Sunshine' (Cucurbita maxima) and three Cucurbita moschata cultigens, breeding lines NH.Mo851 and NH.Mo421, and the cultivar Waltham Butternut (WBN) harvested at $60 \mathrm{~d}$ after pollination. Separation and quantification by highperformance liquid chromatography on a $\mathrm{C}_{30}$ column.

\begin{tabular}{|c|c|c|c|c|c|c|c|c|}
\hline \multicolumn{4}{|c|}{ Other major carotenoids $\left(\mu \mathrm{g} \cdot \mathrm{g}^{-1} \mathrm{FW}\right)^{z}$} & \multicolumn{5}{|c|}{ Nutritionally beneficial carotenoids $\left(\mu \mathrm{g} \cdot \mathrm{g}^{-1} \mathrm{FW}\right)^{\mathrm{z}}$} \\
\hline Cultigens & Neoxanthin & Flavoxanthin & Violaxanthin & Lutein & Zeaxanthin & $\alpha$-Carotene & $\beta$-Carotene & Total \\
\hline 2007 & 33.8 & 15.9 & 0 & 47.5 & 16.5 & 0 & 46.4 & 160.1 \\
\hline 2009 & 24.6 & 25.8 & 0 & 45.9 & 6.8 & 0 & 43.1 & 146.2 \\
\hline ANOVA & 0.033 & NS & & NS & 0.001 & & NS & NS \\
\hline \multicolumn{9}{|l|}{ WBN } \\
\hline 2008 & 13.4 & 0 & 11.0 & 27.3 & 0 & 0.8 & 17.6 & 70.1 \\
\hline \multicolumn{9}{|l|}{ NH.Mo851 } \\
\hline 2007 & 27.5 & 0 & 11.7 & 60.0 & 0 & 0 & 55.4 & 154.6 \\
\hline 2008 & 27.5 & 0 & 9.2 & 59.9 & 0 & 0 & 33.2 & 129.8 \\
\hline ANOVA & NS & & NS & NS & & & 0.028 & NS \\
\hline \multicolumn{9}{|l|}{ NH.Mo421 } \\
\hline 2007 & 16.8 & 0 & 10.0 & 22.7 & 0 & 2.3 & 91.2 & 143.0 \\
\hline 2008 & 21.6 & 0 & 9.4 & 22.3 & 0 & 4.5 & 114.2 & 172.0 \\
\hline
\end{tabular}

${ }^{2}$ Values were adjusted for loss during saponification and extraction using an internal standard $\beta$-apo-8-carotenoate.

ANOVA $=$ analysis of variance.

development (Milborrow, 2001). A recent study showed that expression of a 9-cisepoxycarotenoid dioxygenase gene (responsible for cleavage of neoxanthin and violaxanthin) is key to ABA biosynthesis, and regulation of this gene influences ripening and fruit coloring in strawberry (Fragaria ananassa) (Jia et al., 2011). Thus, knowledge of neoxanthin and violaxanthin biosynthesis and accumulation could be important for squash plant breeding programs.

In comparing concentrations of the nutritionally important carotenoids to total carotenoid concentrations, a higher proportion were found in $C$. moschata, ranging from $65 \%$ to $86 \%$, compared with $41 \%$ to $63 \%$ in C. maxima kabocha squash at 60 DAP (Table 4). Therefore, even though C. maxima hybrids had significantly higher total carotenoid concentrations than $C$. moschata cultigens, the average concentration of carotenoids with known health benefits in the four cultigens of $C$. moschata was only slightly lower $\left(91.6 \mu \mathrm{g} \cdot \mathrm{g}^{-1} \mathrm{FW}\right)$ than in the four hybrid cultigens of $C$. maxima $\left(99.9 \mu \mathrm{g} \cdot \mathrm{g}^{-1} \mathrm{FW}\right)$.

In many studies employing HPLC analysis, carotenoid profiles include only lutein and carotenes, rather than total carotenoid profiles (Arima and Rodriguez-Amaya, 1988; Gonzalez et al., 2001; Itle and Kabelka, 2009; Murkovic et al., 2002). However, in a breeding program initially relying only on visual selection for carotenoid content, knowledge of the concentrations of other carotenoids such as neoxanthin, violaxanthin, and flavoxanthin in the carotenoid profile is important. Furthermore, for breeding processing squash, a higher proportion of carotenes vs. hydroxy carotenoids is desirable because carotenes are more stable to high temperatures during steam cooking (Provesi et al., 2011).

Yearly changes in carotenoid profiles. Carotenoid profiles for the C. maxima hybrid, 'Sunshine' were obtained over three growing seasons, 2007, 2008, and 2009 (Table 5). Total carotenoid concentrations across years were not statistically significant, and the higher total concentration in 2007 could be attributed to a later average harvest period (70 DAP) than in 2008 and 2009 (60 DAP). The major beneficial carotenoids, $\beta$-carotene and lutein, did not differ significantly across years, but neoxanthin and zeaxanthin exhibited significant year to year variability.

In C. moschata, total carotenoid and lutein concentrations were similar across years for the three cultigens analyzed (Table 5). In 'Waltham Butternut', there were significant differences among the carotenoids in 2008 as compared with 2009 , but the differences were small. In NH.Mo851, $\beta$-carotene was $67 \%$ higher in 2007 than in 2008. Carotenoid profiles for the inbred line NH.Mo421 were similar for fruit harvested in 2007 and 2008, and lutein and $\beta$-carotene comprised a high proportion $(0.81-0.82)$ of the total carotenoid profiles during both years (Table 5). In the inbred line NH.Mo851, the proportion of lutein was higher and $\beta$-carotene lower in 2008 as compared with 2007. We are not aware of other studies that have compared yearly differences in carotenoid profiles, but our limited results suggest that overall, carotenoid profiles are fairly consistent from one season to the next, at least in the same locality with similar cultural conditions.

Changes in carotenoid profiles during storage at $14{ }^{\circ} \mathrm{C}$ were compared among two cultivars, Sunshine in C. maxima and Waltham Butternut in C. moschata (Table 6). In 'Sunshine', the total carotenoid concentration more than doubled between 0 - and 60-d storage, but the degree of change varied among the different carotenoids. $\beta$-carotene increased 
Table 6. Changes in carotenoid profiles of 'Sunshine' (Cucurbita maxima) and 'Waltham Butternut' (WBN) (Cucurbita moschata) winter squash harvested at $60 \mathrm{~d}$ after pollination in 2008 and stored for 0,30 , or $60 \mathrm{~d}$ at $14{ }^{\circ} \mathrm{C}$.

\begin{tabular}{|c|c|c|c|c|c|c|c|}
\hline \multirow{2}{*}{$\begin{array}{c}\text { Hybrids } \\
\text { C. maxima }\end{array}$} & \multirow[b]{2}{*}{ Days } & \multicolumn{6}{|c|}{ Carotenoids $\left(\mu \mathrm{g} \cdot \mathrm{g}^{-1} \mathrm{FW}\right)^{z}$} \\
\hline & & Neoxanthin & Flavoxanthin & Lutein & Zeaxanthin & $\beta$-Carotene & Total \\
\hline 'Sunshine' & 30 & $32.7 \mathrm{~b}$ & $29.5 \mathrm{a}$ & $57.5 \mathrm{~b}$ & $23.2 \mathrm{a}$ & $86.0 \mathrm{~b}$ & $228.9 \mathrm{~b}$ \\
\hline \multirow[t]{3}{*}{ WBN } & 0 & $13.4 \mathrm{a}^{\mathrm{y}}$ & $11.0 \mathrm{~b}$ & $27.3 \mathrm{~b}$ & $0.8 \mathrm{a}$ & $17.6 \mathrm{a}$ & $70.1 \mathrm{a}$ \\
\hline & 30 & $19.0 \mathrm{~b}$ & $10.6 \mathrm{~b}$ & $31.0 \mathrm{~b}$ & $1.5 \mathrm{a}$ & $57.8 \mathrm{~b}$ & $119.9 \mathrm{~b}$ \\
\hline & 60 & $26.9 \mathrm{c}$ & $19.0 \mathrm{c}$ & $44.6 \mathrm{c}$ & $1.5 \mathrm{a}$ & $49.2 \mathrm{~b}$ & $141.2 \mathrm{c}$ \\
\hline
\end{tabular}

${ }^{2}$ Values adjusted for loss during extraction and saponification with internal standard, $\beta$-apo-8-carotenoate.

${ }^{y}$ Mean values in columns followed by same letter are not significantly different, Tukey's honestly significant difference test, $P \leq 0.05$.

4-fold, lutein increased by only $32 \%$, and zeaxanthin did not increase. Neoxanthin doubled during 60-d storage and flavoxanthin exhibited nearly a 3-fold increase. The proportion of $\beta$-carotene to total carotenoids was $0.19,0.38$, and 0.58 , respectively, at $0 \mathrm{~d}, 30 \mathrm{~d}$, and 60-d storage. In contrast, the proportion of lutein to total carotenoids decreased from 27.3 at $0 \mathrm{~d}$ to 15.9 at $60-\mathrm{d}$ storage. The proportion of neoxanthin + flavoxanthin to total carotenoids decreased from 0.37 at 0 -d storage to 0.27 at $30 \mathrm{~d}$, but increased to 0.42 at 60 -d storage because of the increased accumulation of flavoxanthin.

In 'Waltham Butternut', the total carotenoid concentration doubled between 0 and $60 \mathrm{~d}$ of storage, however, $\beta$-carotene increased 3 -fold, whereas, lutein increased by only $63 \%$. The neoxanthin concentration doubled between 0 and 60 -d storage and violaxanthin increased by $73 \%$. As a result, the proportion of $\beta$-carotene to total carotenoids increased from 0.25 at $0 \mathrm{~d}$ to 0.48 at $30 \mathrm{~d}$ and then decreased to 0.35 at 60 -d storage. The proportion of lutein, on the other hand, decreased from 0.39 at $0 \mathrm{~d}$ to 0.32 at 60 -d storage.

Previous studies of changes in carotenoid profiles during storage are limited; however, our results indicate that carotenoid profiles can change appreciably during storage, and suggest that $\beta$-carotene may increase more during storage than the xanthophylls. In a kabocha variety of $C$. maxima, Kon and Shimba (1988) reported that total carotenids doubled after 2 months of storage. Lutein comprised 0.64 of the total carotenoid profile before storage and the proportion changed only slightly after 60 -d storage at $10(0.65)$ and $25^{\circ} \mathrm{C}(0.71)$. In contrast, the percentage of $\alpha$-carotene changed from 0.11 at harvest to nondetectible after storage, and the proportion of $\beta$-carotene increased from 0.08 of total carotenoids at harvest to 0.13 at $10{ }^{\circ} \mathrm{C}$ and 0.22 at $25^{\circ} \mathrm{C}$ after storage. Although the proportional changes in $\beta$-carotene were greater than lutein in the above study, incremental increases in lutein at $25{ }^{\circ} \mathrm{C}\left(88 \mu \mathrm{g} \cdot \mathrm{g}^{-1} \mathrm{FW}\right)$ were greater than that for $\beta$-carotene $\left(22 \mu \mathrm{g} \cdot \mathrm{g}^{-1}\right.$ FW). In the butternut cultivar Bugle, Zhang et al. (2014) found a 3-fold increase in total carotenoid concentration in squash stored for 2 months at room temperature; however, there was greater accumulation of $\beta$-carotene than lutein. The proportion of $\beta$-carotene to total carotenoids increased from 0.51 to 0.58 during 2 months of storage; whereas, the proportion of lutein to total carotenoids decreased from 0.36 to 0.21 , and the proportion of violaxanthin increased from 0.13 to 0.21 during the same storage period.

The large increases in $\beta$-carotene during storage has important nutritional implications. For example, storage of butternut squash for 1 to 2 months is generally recommended to attain sufficient soluble solids for acceptable eating quality (Noseworthy and Loy, 2008). In 'Waltham Butternut', $\beta$-carotene concentrations averaged only $17 \mu \mathrm{g} \cdot \mathrm{g}^{-1} \mathrm{FW}$ at harvest (60 DAP), but increased to $58 \mu \mathrm{g} \cdot \mathrm{g}^{-1} \mathrm{FW}$ after 30 -d storage (Table 6), equal to $5800 \mu \mathrm{g}$ in a $100 \mathrm{~g}$ serving of squash. Using the current value for conversion of $\beta$-carotene to retinoic acid of $12 \mu \mathrm{g}$ of $\beta$-carotene equaling $1 \mu \mathrm{g}$ of retinoic acid (Britton, 2009; Tang and Russell, 2009), a $100 \mathrm{~g}$ serving would represent $483 \mu \mathrm{g}$ of retinoic acid, or $\approx 54 \%$ of the recommended daily allowance (RDA) for adult males $(900 \mu \mathrm{g})$ and $69 \%$ of the RDA for adult females $(700 \mu \mathrm{g})$ as reported by the Institute for Medicine, Food and Nutrition Board (National Academy of Sciences, 2001). Furthermore, the more intense orange flesh color associated with higher $\beta$-carotene concentrations after storage of fruit is an important aspect of consumer appeal for the expanding retail marketing of peeled and halved butternut squash.

\section{Conclusions}

In a long-term breeding program at the $\mathrm{UNH}$, we have been able to increase the carotenoid concentration in inbred lines of C. moschata and C. maxima (Table 1) and in hybrids of $C$. maxima (Table 4) through visual selection; however, the shortfall of this system has been the inability to identify which carotenoids were being increased and in determining the proportions of carotenoids known to be nutritionally important in comparison with total carotenoid concentration, as illustrated in Table 4 . Because stage of fruit maturity in squash is difficult to assess visually and carotenoid contents increase substantially in latter stages of maturity (Table 1), our results underscore the importance of determining the time period from fruit set to fruit harvest to accurately evaluate and compare carotenoid contents among cultigens.

Carotenoids usually increased significantly during storage, but in our study, the magnitude of increase was highly cultigen dependent.
Furthermore, in 'Sunshine' (C. maxima) and 'Waltham Butternut' ( $C$. moschata), the proportion of $\beta$-carotene to total carotenoids increased and the proportion of lutein to total carotenoids decreased during storage.

The predominant nutritionally beneficial carotenoids in C. moschata and C. maxima cultigens were lutein and $\beta$-carotene; however, $C$. maxima hybrids also had appreciable concentrations of zeaxanthin. Lutein is a constituent in leafy greens (Kopsell and Kopsell, 2006), but among starchy vegetables, winter squash is one of the most prominent sources of this carotenoid.

A notable result in $C$. maxima was the observation that in the four commercial kabocha/buttercup hybrids examined, between $42 \%$ and $59 \%$ of total carotenoid concentrations were represented by neoxanthin and flavoxanthin, carotenoids not yet found to be important in human nutrition. Thus, the nutritional status could be substantially improved in kabocha cultigens by identifying germplasm with a high proportion of lutein, zeaxanthin, and carotenes in the total carotenoid profile, and introgressing these characteristics into improved breeding lines.

\section{Literature Cited}

Amala-Sujith, A., T. Hymavathi, and P. Yasoda Devi. 2010. Supercritical fluid extraction of lutein esters from marigold flowers and their hydrolysis by improved saponification and enzyme biocatalysis. Intl. J. Biol. Life Sci. 6(2): 67-76.

Arima, H.K. and D.B. Rodriguez-Amaya. 1988. Carotenoid composition and vitamin A value of commercial Brazilian squashes and pumpkins. J. Micronutr. Anal. 4:177-191.

Arvayo-Ortiz, R.M., S. Garza-Ortega, and E.M. Yahia. 1994. Postharvest response of winter squash to hot-water treatment, temperature and length of storage. HortTechnology 4:253-255.

Azevedo-Meleiro, C.H. and D.B. Rodriguez-Amaya. 2007. Qualitative and quantitative differences in carotenoid composition among Cucurbita moschata, Cucurbita maxima, and Cucurbita pepo. J. Agr. Food Chem. 55:4027-4033.

Barua, A.B. and J.A. Olson. 2001. Xanthophyll epoxides, unlike $\beta$-carotene monoepoxides, are not detectibly absorbed by humans. J. Nutr. 131:3212-3215.

Boiteux, L.S., W.M. Nascimento, M.E.N. Fonseca, M.M. Lana, A. Reis, and J.L. Mendonça. 2007. 'Brasileirinha': Cultigen de abóbora (Cucurbita moschata) de frutos bicolores com valor ornamental e aptidão para consumo verde. Hort. Bras. 25:103-106. 
Bonina-Noseworthy, J. 2012. Variability in carotenoid content and profiles in winter squash and sweet potato. Univ. New Hampshire, Durham, NH, PhD. Diss. 143 p., 3537824.

Bowen, P.E., S.M. Herbst-Espinosa, E.A. Hussain, and M. Stacewicz-Sapuntzakis. 2002. Esterification does not impair lutein bioavailability in humans. J. Nutr. 132:3668-3673.

Breithaupt, D.E., P. Weller, M. Wolters, and A. Hahn. 2004. Comparison of plasma responses in human subjects after the ingestion of 3R,3R' -zeaxanthin dipalmitate from wolfberry (Lycium barbarum) and non-esterified 3R,3R' zeaxanthin using chiral high-performance liquid chromatography. Brit. J. Nutr. 91:707-713.

Britton, G. 1985. General carotenoid methods. Methods Enzymol. 111:113-149.

Britton, G. 2009. Vitamin A and vitamin A deficiency, p. 173-190. In: G. Britton, S. LiaaenJensen, and H. Pfander (eds.). Carotenoids, vol. 5: Nutrition and health. Birkhäuser Verlag, Boston, MA.

Britton, G. and F. Khachik. 2009. Carotenoids in foods, p. 45-66. In: G. Britton, S. LiaaenJensen, and H. Pfander (eds.). Carotenoids, vol. 5: Nutrition and health. Birkhäuser Verlag, Boston, MA.

Bycroft, B.L., V.K. Corrigan, and D.E. Irving. 1999. Heat treatments increase sweetness and flesh color in buttercup squash. N.Z. Crop Hort. Sci. 27:265-271.

Canene-Adams, K. and J.W. Erdman. 2009. Absorption, transport, distribution in tissues and bioavailability, p. 115-148. In: G. Britton, S. Liaaen-Jensen, and H. Pfander (eds.). Carotenoids, vol. 5: Nutrition and health. Birkhäuser Verlag, Boston, MA.

de Carvalho, L.M.J., P.B. Gomes, R.L.O. Godoy, S. Pacheco, P.H.F. Monte, J.L.V. Carvalho, M.R. Nutti, A.C.L. Neves, A.C.R.A. Vieira, and S.R.R. Ramos. 2012. Total carotenoid content, alpha and $\beta$-carotene, of landrace pumpkins (Cucurbita moschata Duch): A preliminary study. Food Res. Intl. 47:337-340.

Corrigan, V.K., P.L. Hurst, and J.F. Potter. 2001. Winter squash (Cucurbita maxima) texture: Sensory, chemical, and physical measures. N.Z. Crop Hort. Sci. 29:111-124.

de Rosso, V. and A. Mercandante. 2007. Evaluation of colour and stability of anthocyanins from tropical fruits in an isotonic soft drink system. Innov. Food Sci. Emerg. Technol. 8:347-352.

González, E., M.A. Montenegro, M.A. Nazareno, and B.A. López de Mishima. 2001. Carotenoid composition and vitamin A value of an Argentinian squash (Cucurbita moschata). Arch. Latinoam. Nutr. 51:395-399.

Harvey, W.J., D.G. Grant, and J.P. Lammerink. 1997. Physical and sensory changes during development and storage of buttercup squash. N.Z. Crop Hort. Sci. 25:341-351.

Hopp, R.J., S.B. Merrow, and E.M. Elbert. 1960. Varietal differences and storage changes in $\beta$-carotene content of six varieties of winter squashes. Proc. Amer. Soc. Hort. Sci. 76:568576.

Howell, J.A., R. Bonanno, T.J. Boucher, R.V. Hazzard, and R. Wick. 2007. 2006-2007 New England Vegetable Management Guide. Univ. Mass. Extension, 140 p.

Humphries, J.M. and F. Khachik. 2003. Distribution of lutein, zeaxanthin, and related geometric isomers in fruit, vegetables, wheat, and pasta products. J. Agr. Food Chem. 51:13221327.

Hurst, P., V. Corrigan, P. Hannan, and R. Lill. 1995. Storage rots, compositional analysis, and sensory quality of three cultigens of buttercup squash. N.Z. Crop Hort. Sci. 23:89-95.

Irving, D.E., P.L. Hurst, and J.S. Ragg. 1997. Changes in carbohydrates and carbohydrate metabolizing enzymes during the development, maturation, and ripening of buttercup squash (Cucurbita maxima D. 'Delica'). J. Amer. Soc. Hort. Sci. 122:310-314.

Itle, R. and E. Kabelka. 2009. Correlation between $\mathrm{L} * \mathrm{a} * \mathrm{~b} *$ color space values and carotenoid content in pumpkins and squash (Cucurbita spp.). HortScience 44:633-637.

Jacobo-Valenzuela, N., J. Zazueta-Morales, J.A. Gallegos-Infante, F.A. Aguilar-Gutierrez, I. Camacho-Hernandez, E. Rocha-Guzman, and R. Gonzalez-Laredo. 2011. Chemical and physicochemical characterization of winter squash (Cucurbita moschata D.). Not. Bot. Hort. Agrobot. Cluj. 39:34-40.

Jia, H.-F., Y.-M. Chai, C.-L. Li, D. Lu, J.-J. Luo, L. Qin, and Y.-Y. Shen. 2011. Abscisic acid plays an important role in the regulation of strawberry fruit ripening. Plant Physiol. 157:188199.

Khachik, F. 2009. Analysis of carotenoids in nutritional studies, p. 7-44. In: G. Britton, S. Liaaen-Jensen, and H. Pfander (eds.). Carotenoids, vol. 5: Nutrition and health. Birkhäuser Verlag, Boston, MA.

Khachik, F. and G.R. Beecher. 1988. Separation and identification of carotenoids and carotenol fatty acid esters in some squash products by liquid chromatography. 1. Quantification of carotenoids and related esters by HPLC. J. Agr. Food Chem. 36:929-937.

Khachik, F., G.R. Beecher, and W.R. Lusby. 1988. Separation and identification of carotenoids and carotenol fatty-acid esters in some squash products by liquid chromatography. 2. Isolation and characterization of carotenoids and related esters. J. Agr. Food Chem. 36:938-946.

Kon, M. and R. Shimba. 1988. Accumulation of carotenoids in squash. J. Home Econ. Japan 39:1059-1064.

Kopsell, D.A., T. Casey Barickman, C.E. Sams, and J.S. McElroy. 2007. Influence of nitrogen and sulfur on biomass and carotenoid and glucosinolate concentrations in watercress (Nasturtium officinale R. Br.). J. Agr. Food Chem. 55:10628-10634.

Kopsell, D.A. and D.E. Kopsell. 2006. Accumulation and bioavailability of dietary carotenoids in vegetable crops. Trends Plant Sci. 11:499507.

Loy, J.B. 2004. Morpho-physiological aspects of productivity and quality in squash and pumpkins (Cucurbita spp.). Crit. Rev. Plant Sci. 23:337-363.

Milborrow, B.V. 2001. The pathway of biosynthesis of abscisic acid in vascular plants: A review of the present state of knowledge of ABA biosynthesis. J. Expt. Bot. 52:1145-1164.

Moss, G.P. and B.C.L. Weedon. 1976. Chemistry of the carotenoids, p. 149-224. In: T.W. Goodwin (ed.). Chemistry and biochemistry of plant pigments, 2nd ed. Academic Press, New York, NY.
Murkovic, M., M. Mülleder, and H. Neunteufl. 2002. Carotenoid content in different varieties of pumpkins. J. Food Compos. Anal. 15:633638.

Mutschler, M.A. and O.H. Pearson. 1987. The origin, inheritance, and instability of butternut squash (Cucurbita moschata Duchesne). HortScience 22:535-539.

National Academy of Sciences. 2001. Dietary reference intakes for vitamin $\mathrm{A}$, vitamin $\mathrm{K}$, arsenic, boron, chromium, copper, iodine, iron, manganese, molybdenum, nickel, silicon, vanadium, and zinc. Institute of Medicine, Food and Nutrition Board, Panel on Micronutrients. Natl. Acad. Press, Washington, D.C.

Noseworthy, J. and B. Loy. 2008. Improving eating quality and carotenoid content of squash, p. 521-528. In: M. Pitrat (ed.). Cucurbitaceae 2008, Proc. IXth EUCARPIA Meeting on Genetics and Breeding of Cucurbitaceae. INRA, Avignon, France.

Paris, H.S. and R.N. Brown. 2005. The genes of pumpkins and squash. HortScience 40:16201630.

Provesi, J.G., C.O. Dias, and E.R. Amante. 2011. Changes in carotenoids during processing and storage of pumpkin puree. Food Chem. 128:195-202.

Rodriguez-Amaya, D.B. 2001. A guide to carotenoid analysis in food. ILSI Press, Washington D.C.

Schaffer, A., H.S. Paris, and I.M. Ascarelli. 1986. Carotenoid and starch content of near isogenic $\mathrm{B}^{+} \mathrm{B}^{+}$and $\mathrm{BB}$ genotypes of Cucurbita. J. Amer. Soc. Hort. Sci. 111:780-783.

Schalch, W., J.T. Landrum, and R.A. Bone. 2009. The eye, p. 301-334. In: G. Britton, S. LiaaenJensen, and H. Pfander (eds.). Carotenoids, vol. 5: Nutrition and health. Birkhäuser Verlag, Boston, MA.

Tadmoor, Y., H.S. Paris, A. Meir, A.A. Schaffer, and E. Lewinsohn. 2005. Dual role of the pigmentation gene $\mathrm{B}$ in affecting carotenoids and vitamin E content in squash (Cucurbita реро) mesocarp. J. Agr. Food Chem. 53:97599763.

Tang, G. and R.M. Russell. 2009. Carotenoids as Provitamin A, p. 149-172. In: G. Britton, S. Liaaen-Jensen, and H. Pfander (eds.). Carotenoids, vol. 5: Nutrition and health. Birkhäuser Verlag, Boston, MA.

Toomey, M. and K. McGraw. 2007. Modified saponification and HPLC methods for analyzing carotenoids from the retina of quail: Implications for its use as a non-primate model species. Invest. Ophthalmol. Vis. Sci. 48:3976-3982.

Vining, K.J. and J.B. Loy. 1998. Seed development and seed fill in hull-less seeded cultigens of pumpkin (Cucurbita pepo L.), p. 64-69. In: J.M. McCreight (ed.). Cucurbitaceae 98: Evaluation and enhancement of cucurbit germplasm. ASHS Press, Alexandria, VA.

Yeager, A.F. and E.M. Meader. 1957. Breeding new vegetable varieties. NH Agr. Expt. Sta. Bul. 440:1-32.

Zaccari, F. and G. Galietta. 2015. $\alpha$-carotene and $\beta$-carotene content in raw and cooked pulp of three mature stage winter squash "type butternut". Foods 4:477-486.

Zhang, M.K., M.P. Zhang, M. Mazourek, Y. Tadmor, and L. Li. 2014. Regulatory control of carotenoid accumulation in winter squash during storage. Planta 240:1063-1074. 